\title{
Pedagogical Tools to Enhance the Cognitive Skills of (Humanitarian) Design Engineers: The Rationale
}

\author{
Thomas H. Colledge, PhD, PE \\ Engineering and Community Engagement \\ The Pennsylvania State University \\ thc100@psu.edu
}

\begin{abstract}
This is the first of a series of papers which seek to elaborate upon the cognitive and metacognitive skills which industry has identified as needed by engineers and the descriptions of the pedagogical tools to better prepare the prospective engineers for the careers that lie ahead of them. The papers describe an alternative way of conceptualizing the engineering curriculum by shifting the focus from learning engineering as a body of disparate knowledge consisting of science courses, engineering science courses, and analysis courses to understanding engineering as a way of thinking - promoting deeper conceptual understanding of core fundamental ideas and preparing students to be lifelong learners. Focus is placed on the pedagogy for enhancing the cognitive aspects of thinking including adaptive expertise, selfregulated learning, problem-solving skills, critical thinking skills, metacognition and workplace thinking-incorporating engaged scholarship at its core.
\end{abstract}

Index: service learning in engineering, engineering design, adaptive expertise, self-regulated learning, problem solving, critical thinking, workplace learning

\section{INTRODUCTION}

Educational reforms which have sought to better prepare future engineering graduates to address complex challenges have been ongoing for decades now. These skills include not only domain specific knowledge, but also a set of transferable skills in multidisciplinary teamwork, communication, creativity, business, systems thinking, design thinking and independent learning ${ }^{1,2,3}$. In addition, today's engineering graduates must possess personal traits that nurture a deep ethical development, lifelong learning, and a commitment to meeting society's grand challenges.

Employers of engineering graduates express interest in having new employees be more 'job ready'; that is, proficient at problem solving, thinking critically, and managing projects - all in a workplace environment ${ }^{4}$. It has been recognized that being successful in today's highly technological and globally competitive world requires a person to develop and use a different set of skills than were needed before ${ }^{5}$. Many studies have converged on a view of engineering education that not only requires students to grasp traditional engineering fundamentals, such as mechanics, dynamics, mathematics, and technology, but to also develop the skills associated with learning to imbed this knowledge in real-world situations ${ }^{6}$. This vision of engineering requires engineers be trained to learn to be lifelong learners and learn to develop adaptive expertise ${ }^{7,8}$ as well as be self-regulated learners.

Yet, the apparent paradoxes that emerge in attempting to develop curricula for engineering design students to develop such skills are daunting. There is tension between rigor and heuristics; 
International Journal for Service Learning in Engineering,

Humanitarian Engineering and Social Entrepreneurship

Vol. 12, No. 1, pp. 74-89, Spring 2017

ISSN 1555-9033

the need to encourage both divergent and convergent thinking; the need to be simultaneously systematic and creative; the need to perform both analysis and synthesis; the need for the design engineer to be both a generalist and a specialist; and the need for the design engineer to take both a systems view and a detail view. The challenges are there to confront ${ }^{9}$.

Unfortunately, much of the engineering curricula require students to learn in unconnected pieces. They take separate courses whose relationship to each other and to the engineering process is not explained until late in their undergraduate education, if ever. Further, engineering curricula usually present the set of topics engineers "need to know," leading to the feeling that an engineering education is simply a collection of courses. While the content of the courses may be valuable, this view of engineering education ignores the need for connections and integration ${ }^{10}$. According to the National Academies, one of two major tasks required to generate desired student learning outcomes is "better alignment of engineering curricula and the nature of academic experiences with the challenges and opportunities graduates will face in the workplace"11. In fact, the same report states that "the disconnect between the system of engineering education and the practice of engineering appears to be accelerating" 10 .

The volume of information that engineers are collectively called upon to know is increasing far more rapidly than the ability of engineering curricula to "cover it." Structuring a four-year or even a five-year engineering curriculum that meets the needs of most engineering students appears to be an increasingly elusive goal ${ }^{12}$. No matter how many parallel tracks and elective courses are offered, however, it will never be possible to teach engineering students everything they will be required to know when they go to work.

A better solution may be to shift the emphasis away from providing training in an everincreasing number of specialty areas to providing a core set of science and engineering fundamentals ${ }^{13,14}$, helping students integrate knowledge across courses and disciplines ${ }^{15}$, and equipping them with lifelong learning skills ${ }^{16,17}$. Students should acquire a repertoire of cognitive and metacognitive skills and strategies that can be used when engaged in design activity such as problem solving, decision making, and inquiry ${ }^{18}$. Cognitive and metacognitive skills are important thinking processes required for problem solving, and these skills should be taught to students. In other words, the focus in engineering education shifts away from the simple presentation of knowledge and toward the integration of knowledge and the development of critical thinking skills needed to make appropriate use of it.

\section{INDUSTRY NEEDS AND UNIVERSITY TRAINING}

As noted above, advances in technology and scientific knowledge have led to an ever increasing amount of content being taught to students. ${ }^{19}$ Teaching students more in the same amount of time leads to the preference of procedural knowledge that prevents adaptive expertise. ${ }^{20,21,21}$

Additionally, the increased content load discourages professors from incorporating active learning strategies into the classroom that explicate reflective or critical thinking. A student might have all the knowledge in the world, but if they are never given an opportunity to learn it at a conceptual level and integrate it with previous knowledge or to practice transferring that knowledge to new situations, that knowledge is useless. Thus, is it better to develop skills to become adaptive experts and hope students learn more content knowledge later in their careers, or better to deliver the content and hope students become effective thinkers later? ${ }^{22}$ 
International Journal for Service Learning in Engineering,

Humanitarian Engineering and Social Entrepreneurship

Vol. 12, No. 1, pp. 74-89, Spring 2017

ISSN 1555-9033

\section{Industry Needs}

Numerous studies have highlighted the needs of industry for engineering graduates to be competent in a host of areas, many of which are not traditionally assessed at the university. For example, the American Society of Engineering Education (ASEE) report entitled 'Transforming Undergraduate Education in Engineering - Synthesizing and Integrating Industry Perspectives' concluded that acquisition of many competencies (see Table 1) expected of engineering students is primarily the responsibility of the university - not industry ${ }^{23}$.

Another example is a study entitled 'Design engineering competencies: Future Requirements and Predicted Changes in the Forthcoming Decade' sought to identify a competency profile for future design engineers. (See Table 1) The study indicated that there is evidence to suggest that the future design engineering role may be changing. Although technical competencies are forecast to remain equally important in the future, their relative importance is set to decline as a consequence of the emerging importance of non-technical competencies ${ }^{24}$.

A third example is the CDIO Initiative (Conceive-Design-Implement-Operate). The CDIO Initiative is an international collaboration between engineering schools to redevelop engineering education to meet the needs of industry. It is a syllabus for undergraduate engineering education which creates a rational, complete, universal, and generalizable set of goals for undergraduate engineering education. ${ }^{25}$

Table 1 provides a synthesis of the competencies and goals identified in these selected reports.

TABLE 1

INDUSTRY-IDENTIFIED NEEDS*

ID, formulate and solve engineering problems

Identify the relevant context of the problem

Identify methods best suited to solve the problem

Identify knowledge needed to address problem

Critical thinking

Technical intuition

Metacognition

Understanding design

Teamwork

Deal with ambiguity

Deal with complexity

Apply knowledge to the real world

Data interpretation

Science/Engineering fundamentals

Creativity/Innovation

Application-based research

Assertive

Design thinking
Enjoys challenges

Open-minded

Proactively seeks training

Plans work

Monitors progress

Understands the task

Conducts risk assessments

Judges importance

Analyzes tasks

Identifies factors

Learns from mistakes

Able to learn

Uses effective learning methods

Technically versatile

Summarizes information

Leadership

Communication skills

Attends to details when communicating

*As identified in the ASEE 'Transforming Undergraduate Education in Engineering - Synthesizing and Integrating Industry Perspectives' Report and the 'Design engineering competencies: Future Requirements and Predicted Changes in the Forthcoming Decade' Report, and the CDIO Initiative. 
International Journal for Service Learning in Engineering, Humanitarian Engineering and Social Entrepreneurship

Vol. 12, No. 1, pp. 74-89, Spring 2017

ISSN 1555-9033

\section{University Approaches to Achieve Goals}

Instructors use many alternative approaches to teaching courses that present fundamental and often difficult engineering content. The most common approach is a didactic lecture format, which has numerous demonstrated benefits. Students receive a clear exposition of the information they need to learn, teachers can be sure they have covered the content if they follow well-organized materials that are readily available, and students tend to learn content well as measured by performance on tests that replicate the content and context under which the material was presented ${ }^{26,27,28}$.

However, there are drawbacks to the lecture approach as well. Students may learn the material in a disconnected fashion that makes it difficult for them to apply their knowledge out of context, and their long-term retention is often poor ${ }^{29,30}$. Further, students have difficulty in relating their accrued knowledge to problems in the "real world" - in the workplace or graduate school ${ }^{31,32}$.

An alternate teaching approach is to apply one of several methods that can be grouped together as inquiry learning. Problem- and project-based learning, case-based learning, authentic inquiry, and discovery learning are all examples ${ }^{33,34,35,36,37,38}$. Features of these methods are that they engage students in authentic problems without single correct solutions, they allow extended student exploration, and theories, principles and formalisms are taught when the need to know them has been established. These approaches increase student motivation and awareness of the connections between their in-class experiences and their future work, lead to positive attitudes about learning for both students and teachers, and, when structured well, lead to significant increases in knowledge ${ }^{39,40}$.

However, like traditional lecture, inquiry methods can have drawbacks. Without extensive training, teachers often have trouble selecting problems that highlight the key principles in the discipline, opting rather for problems that merely seem engaging ${ }^{41}$. Students consequently often miss important concepts they need to learn ${ }^{42}$. Students may have trouble structuring their approach to these open-ended problems if they have not also learned the fundamental principles for the subject and how to apply them with an effective analysis strategy ${ }^{43}$. Thus, they may struggle with the processes such as hypothesis generation, defining appropriate systems for investigation, and confining the breadth of their investigation to answer the question asked. Finally, if these approaches are not structured well, students' knowledge gains are less than in lecture-based educational settings $s^{44,45,46}$.

In many engineering curricula, students will have a chance to practice the skills sought by industry only in the capstone experience in the final year of study. Even two design experiences do not improve students' ability to consider broader context in their design process ${ }^{47}$. Thus, it is clear that students would benefit from a greater number of opportunities to address authentic problems.

Table 2 attempts to categorize the industry-identified needs for engineers listed in Table 1 in an attempt to better discern pedagogies which may better prepare students for their professions. 
International Journal for Service Learning in Engineering,

Humanitarian Engineering and Social Entrepreneurship

Vol. 12, No. 1, pp. 74-89, Spring 2017

ISSN 1555-9033

TABLE 2

CATEGORIZATION OF INDUSTRY-IDENTIFIED NEEDS

\begin{tabular}{|c|c|c|c|c|}
\hline $\begin{array}{c}\text { Technical and Design } \\
\text { Focused }\end{array}$ & $\begin{array}{l}\text { Dispositions, } \\
\text { Traits \& } \\
\text { Performance } \\
\text { Skills }\end{array}$ & Cognitive skills & $\begin{array}{l}\text { Metacognitive } \\
\text { Skills }\end{array}$ & $\begin{array}{l}\text { Metacognitive } \\
\text { Skills }\end{array}$ \\
\hline $\begin{array}{l}\text { ID, formulate and solve } \\
\text { engineering problems }\end{array}$ & Assertive & Critical thinking & Deals with ambiguity & $\begin{array}{l}\text { Proactively seeks } \\
\text { training }\end{array}$ \\
\hline $\begin{array}{l}\text { Science/Engineering } \\
\text { fundamentals }\end{array}$ & Open-minded & $\begin{array}{c}\text { Creative/Innovative } \\
\text { thinking }\end{array}$ & $\begin{array}{l}\text { Deals with } \\
\text { complexity }\end{array}$ & Plans Work \\
\hline Data interpretation & $\begin{array}{l}\text { Enjoys } \\
\text { challenges }\end{array}$ & Design thinking & Judges importance & $\begin{array}{l}\text { Monitors } \\
\text { progress }\end{array}$ \\
\hline $\begin{array}{l}\text { Apply knowledge to the } \\
\text { real world }\end{array}$ & $\begin{array}{l}\text { Leadership } \\
\text { skills }\end{array}$ & Problem solving & $\begin{array}{l}\text { Summarizes } \\
\text { information }\end{array}$ & Metacognition \\
\hline Understanding of design & $\begin{array}{l}\text { Teamwork } \\
\text { skills }\end{array}$ & Systems thinking & Analyzes tasks & $\begin{array}{l}\text { Learns from } \\
\text { mistakes }\end{array}$ \\
\hline Understands the task & $\begin{array}{l}\text { Communication } \\
\text { skills }\end{array}$ & Adaptive expertise & $\begin{array}{l}\text { Identifies knowledge } \\
\text { and methods to } \\
\text { address problems }\end{array}$ & Able to learn \\
\hline $\begin{array}{l}\text { Conducts risk } \\
\text { assessments }\end{array}$ & $\begin{array}{l}\text { Technically } \\
\text { versatile }\end{array}$ & & $\begin{array}{c}\text { Identifies relevant } \\
\text { contexts of problems }\end{array}$ & $\begin{array}{c}\text { Use effective } \\
\text { learning methods }\end{array}$ \\
\hline $\begin{array}{l}\text { Application-based } \\
\text { research } \\
\end{array}$ & & & Self-regulation & $\begin{array}{c}\text { Technical } \\
\text { intution }\end{array}$ \\
\hline $\begin{array}{c}\text { More Traditional } \\
\text { Engineering Content }\end{array}$ & & & $\begin{array}{r}\text { Evo } \\
\text { Ide }\end{array}$ & $\begin{array}{l}\text { ing Industry- } \\
\text { tified Needs }\end{array}$ \\
\hline
\end{tabular}

The 'Technical and Design Focused' needs listed in column 1 above are addressed in the traditional engineering curriculum via lectures, practicums, homework and demonstration. The 'Dispositions, Traits \& Performance Skills' needs listed in column 2 are a bit more difficult to address. Student's personal attributes come to the university with them and those traits and dispositions are not commonly addressed. However, over the past decade or two significant efforts has been exerted to develop student leadership, teamwork and communication skills. Columns 3 and 4, 'Cognitive Skills' and 'Metacognitive Skills', are what this series of papers focus on. These are the skills that are consistently identified by industry as being needed by the engineers they employ.

Many of these cognitive and metacognitive skills, and their development, have not been core objectives in the traditional engineering curriculum. They are indeed recognized as being of value, but are not addressed in a formal fashion, iterated upon, and assessed. They do help however to define the type of engineer that firms seek to employ. They also represent to a large extent the $21^{\text {st }}$ century skills that are sought for all learners.

\section{Engineering Thinking}

Engineering thinking, as a concept, can be deconstructed into a set of cognitive competencies and habits within a larger framework, whether it be critical thinking, problem solving, systems 
International Journal for Service Learning in Engineering,

Humanitarian Engineering and Social Entrepreneurship

Vol. 12, No. 1, pp. 74-89, Spring 2017

ISSN 1555-9033

thinking, creative/innovative thinking, or design thinking. Like all thinking, at its core, engineering thinking is an exercise in cognition, and relies upon high-order cognitive skills and a knowledge of why, when, and how to utilize them. ${ }^{48}$

Understanding engineering thinking as an emergent property of some of these highly refined cognitive skills enables engineering instructors to begin to develop a prescriptive approach for teaching and implementing engineering thinking methodologies with their students. ${ }^{47}$ According to the Stanford Encyclopedia of Philosophy, "emergent entities 'arise' out of more fundamental entities and yet are 'novel' or 'irreducible' with respect to them"49. Because true emergent properties are irreducible, they cannot be destroyed or decomposed - they appear or disappear instead. In this sense, engineering thinking may seem to exist as a stand-alone concept, but if examined closely - if the components are examined more closely - it vanishes into its components. $^{50}$

Understood in this way, well-established fields such as neuroscience and cognitive science can be employed in building a strong case for studying and exploring the cognitive and metacognitive skills sought by engineering employers identified in Table $2 .{ }^{47}$

It is proposed that the mastery of cognitive and metacognitive skills listed in Table 2, employed to facilitate the emergent property of engineering thinking, will facilitate successful transfer of engineering thinking skills to novel problem types; that is, enhance adaptive expertise and self-regulated learning. The challenge is to determine how best to achieve such cognitive and metacognitive skills development, in an academic setting, that would be of value to engineering students and their prospective employers. This challenge involves the student undertaking the study of the theory and underlying foundations of such cognitive and metacognitive skills, as well as their application and assessment in a discipline-specific fashion, in order to facilitate transfer and enhance the student's adaptive expertise and self-regulated learning skills.

\section{Transfer}

Transfer may be defined as the use of previous learning in a situation somewhat different from the situation in which learning took place. ${ }^{51}$ Some have suggested that if someone responds in a relatively skillful or habitual way, it is evidence of learning, or remembering. If the situation is at least superficially different from the original situation it indicates that transfer has occurred. If the needed response is not obvious, the behavior might be described as problem solving. And, if learning is applied in a situation very different from that in which it was learned, we describe it as creativity. ${ }^{50}$

There are a number of factors that affect learning transfer. ${ }^{52}$ These include: a) whether students understand or simply memorize knowledge, b) the amount of time spent on learning the task, c) the amount of deliberate practice that is done beyond learning the task, d) the motivation of the student, e) how the problem is represented, f) the transfer conditions, and g) the metacognition of the student ${ }^{53} 54,55,56,57$. Items a, d, e, f and g may not be addressed as thoroughly as they should in the more traditional classroom environment and thus require more attention.

Two broad categories of transfer are described in the literature - near transfer and far transfer. Near transfer occurs when students apply their knowledge and skills in situations and contexts that are very similar to those in which the learning occurred. ${ }^{51}$ In contrast, a far transfer occurs when a skill is performed in a context that is very different from the context in which the skill was learned. 
International Journal for Service Learning in Engineering,

Humanitarian Engineering and Social Entrepreneurship

Vol. 12, No. 1, pp. 74-89, Spring 2017

ISSN 1555-9033

The opportunities for far transfer in problem solving within the classrooms are understandably not as regular as the opportunities for near transfer. ${ }^{51}$ Far transfer is more difficult "because students must deliberately analyze the situation in order to recall the rules or concepts that are needed to apply their knowledge and skill in that particular situation ${ }^{52,58}$.

Good and poor problem solvers differ in their recall of information from previously encountered problems and by extension their ability to transfer concepts to the target problem. This difference exists because poor problem solvers tend to remember surface similarities between problems, while good problem solvers remember underlying conceptual structures that make two problems similar although they have different surface features. ${ }^{59}$ This ability of good problem solvers makes it easier to transfer concepts learned in other domains or from solving other types of problems because of their conscious effort to abstract knowledge and concepts from one context for application to another. ${ }^{52,60}$

Cognitive research shows that the organization of learning and how new learning relates to what a student already knows are the strongest predictors of how well a student will transfer knowledge. ${ }^{61}$ Also, reported was that science and engineering students often "lack relevant conceptual frameworks or have frameworks that are not developed enough to support new learning adequately". ${ }^{52,62}$ The absence of such frameworks makes it difficult for students to connect and apply other knowledge where relevant.

The problem-solving process involves several aspects from which three major facets tend to emerge: a) the student's representation of the problem, b) the student's background experiences, and c) the student's understanding of the problem". ${ }^{58}$

\section{Representation}

Representation in the problem-solving process refers to how the student mentally represents the problem. The student's representation of the problem is directly related to his or her existing knowledge structure of the content of the problem. Students trained on specific task components without being provided with the principles underlying the problems, could do specific tasks well but they could not apply their learning to new problems. By contrast, the students who received abstract training showed transfer to new problems that involved analogous relations". ${ }^{52,60}$ Research also shows that engaging students in the solutions of different types of problems in different contexts can enhance transfer by enabling learners to think flexibly about complex domains. ${ }^{63}$ Various types of mental representations are used by students and experts alike in order to understand a problem and to facilitate transfer, particularly, but not limited to, representations such as analogies, metaphors, and propositions are used in the solving of ill-structured problems such as engineering design. ${ }^{64,65,66}$

\section{Understanding}

A student's comprehension of a problem and their ultimate ability to transfer concepts learned previously to the current problem is inextricably linked to his or her ability to properly represent the problem. Embedded within each representation are concepts that the student deems analogous to the problem being tackled, and he or she will transfer these concepts to arrive at a satisfying solution. ${ }^{52}$ 
International Journal for Service Learning in Engineering, Humanitarian Engineering and Social Entrepreneurship Vol. 12, No. 1, pp. 74-89, Spring 2017

ISSN 1555-9033

A philosophical underpinning of programs that integrate the STEM domains is the learning of concepts in one domain, such as science or technology, will facilitate the learning of concepts in other domains, such as mathematics or engineering. Students who can identify the connection between concepts across domains will likely demonstrate an understanding of the problem. While a superior understanding of a problem is demonstrated by the transfer of concepts, knowledge, or processes without prompting, sometimes the use of prompting is necessary. Prompting can dramatically improve the rate of transfer in problem solving. ${ }^{52,67,68}$

A good understanding of the problem will also be reflected in how solvers use metacognitive skills. Metacognition refers to how problem solvers are able to self-regulate the strategies that they use. When students are cognizant of the requirements of a problem, they will more proficiently focus on critical elements of the problem, connect or abstract common themes from previous problem solving episodes or learning experience, and evaluate their progress towards the right solution for well-structured problems or a good solution for ill-structured problems. ${ }^{52,58,60}$

\section{Experiences}

Each student possesses different conceptual knowledge and will make different associations to their knowledge. The student's prior experience helps to establish an understanding of the problem. The process of understanding is iterative, and full understanding is often complex. When the student completely understands the problem and its underlying structure, then transfer to similar situations can occur..$^{52,58}$

Students bring a wealth of knowledge to each learning situation and, without specific guidance from teachers, may fail to connect everyday knowledge to subjects taught in schools. ${ }^{60}$ As students' metacognitive skills develop, their ability to make connections to their learning experiences in the classroom, and beyond the classroom, becomes more self-regulated and automatic when solving problems.

One view of learning transfer is that students find it difficult to transfer concepts that they learn in schools to the real world because education simplifies material to make it easier to teach. ${ }^{62}$ When students are exposed to multiple contexts in their instructions that include examples that demonstrate a wide application of what is being taught, they develop a flexible representation of knowledge and are likely to abstract the relevant features of concepts that make two unique problem scenarios similar. $52,62,66$

\section{Service Learning}

There is a growing sentiment that problem-based and project-based learning can enhance students' general learning transfer and problem-solving skills. ${ }^{69}$ For example, faculty and students who engage in collaboration with community-based entities to effect positive change while concurrently challenging engineering students in an academic setting have experienced learning outcomes benefiting students, faculty, educational institutions, and community partners $^{70,71,72,73,74,75,76,77,78,79}$. Such service learning has proven so overwhelmingly successful that the Kellogg Commission concluded that it "should be viewed as among the most powerful of teaching procedures, if the teaching goal is lasting learning that can be used to shape student's lives around the world ${ }^{80}$." 
International Journal for Service Learning in Engineering,

Humanitarian Engineering and Social Entrepreneurship

Vol. 12, No. 1, pp. 74-89, Spring 2017

ISSN 1555-9033

Service learning pedagogies have been researched and implemented at many universities and their engineering programs over the past 20 years. Efforts have been labeled with various titles including: 'service learning (SL)', or 'engaged scholarship', or 'learning through service', among others.

It is well established that SL has a positive impact on students' academic learning, moral development, improves students' ability to apply what they have learned in the "real world", and improves academic outcomes as demonstrated complexity of understanding, problem analysis, critical thinking, and cognitive development ${ }^{81,82,83,84,85}$.

A wide range of student learning outcomes have been achieved in engineering using $\mathrm{SL}^{86}$. This included all of the ABET a-k outcomes ${ }^{87}$, many of the additional ASCE Body of Knowledge 2nd edition outcomes ${ }^{88}$, and additional attributes. Engineers Without Borders activities have been mapped with all of the ABET a-k outcomes ${ }^{79,89}$. Faculty who have incorporated SL into courses have direct evidence of student learning via students' performance on traditional graded assessments, such as homework, lab reports, and exams. Additional research-based benefits of SL not identified in industry surveys include: spiritual and moral development, self-efficacy, social responsibility, and citizenship.

The true power of SL however may be its ability to achieve a wide array of learning outcomes in an efficient manner that is equally as effective as other methods that are more targeted. Yet, such pedagogies alone are not sufficient to develop the skills prerequisite to expert professional practice and solving complex problems. Developing the additional skills necessary such as the ability to identify the nature and relevant context of the problem, what knowledge is needed to address it, and what methods are best suited to solve the problem can only come with practice in solving complex problems. Theory, iteration, and vertical integration of such are necessary to develop adaptive expertise and self-regulated learning to better prepare engineers for the workplace. $^{79}$

There are three common types of engineering classes where engaged scholarship has been implemented: design (any level from first year to capstone design), experimental lab courses, and analysis-based engineering science (i.e. thermodynamics, fluid mechanics). Integration into design courses appears the most common. There are also organizations that facilitate SL which are very popular with students (i.e. Engineers for a Sustainable World (ESW), Engineers Without Borders (EWB)).

There are many examples of SL in first year introduction and/or projects courses ${ }^{79,90,91,92}$. In many of these courses, SL projects are among many choices available to students or selected as the topic for a particular section of the course. Often these courses are very large, which poses coordination challenges. There are also many examples of SL projects in capstone design courses $^{93,94,95}$. Examples of SL integration into core engineering courses have been less commonly published $^{96,97}$. Beyond specific, individual courses, there are broader curricular efforts (many originally sponsored by the National Science Foundation (NSF)), programs, certificates, and extracurricular organizations that embrace engineering engaged scholarship.

However, service learning endeavors alone are not sufficient to successfully develop the skills prerequisite to expert professional engineering practice and solving complex problems. Attainment of many of the industry-identified skills listed in Table 2 can only come with practice in solving complex problems with scaffolded feedback. SL efforts may touch upon many of the 
International Journal for Service Learning in Engineering,

Humanitarian Engineering and Social Entrepreneurship

Vol. 12, No. 1, pp. 74-89, Spring 2017

ISSN 1555-9033

goals listed, but training in lifelong learning skills, such as: the theory and practice of problem solving, critical thinking, metacognition, an understanding of the philosophy of engineering, all with iterative practice, scaffolding and assessment, is warranted. That is, development of engineering thinking as an emergent property requires student development of adaptive expertise and self-regulated learning skills.

\section{SUMMARY}

An emphasis on understanding how to optimally educate engineers to be self-regulated learners through development of adaptive experts possessing the appropriate cognitive skills should enable university engineering programs to produce higher quality practitioners who can contribute to their fields earlier, and throughout, their careers. ${ }^{98,99,100}$ Unfortunately, the ever increasing load of content knowledge delivered to students, the current delivery methods for that content, time constraints, and large class sizes significantly limit the ability of students to adequately develop these skills. ${ }^{96,97,98}$ Ultimately, the engineering curriculum may require changes to engage and challenge students to inquire and solve problems rather than to simply inform students what and how to think. ${ }^{101,102}$ Of course the use of active learning techniques fosters these skills, but implementation is often conducted without explicit attention to the specific cognitive skills. ${ }^{103}$ These cognitive skills are most certainly all qualities an engineer should embody, but integrating them into the curriculum instill those skills more effectively.

By thinking of engineering thinking as an emergent property consisting of a set of cognitive competencies and habits within a larger framework, incorporating critical thinking, problem solving, systems thinking, creative/innovative thinking, and design thinking among others, engineering educators may begin to develop a prescriptive approach for teaching and implementing methodologies to better prepare their students to meet the needs of employers in the years ahead.

\section{A WAY FORWARD}

The task to determine how to effectively incorporate opportunities to strengthen these skills may be difficult, but certainly needs to be addressed. Specific courses could be taught with the pure intention of developing each skill, or the skills could be sprinkled into other courses throughout the entire curriculum by making classes more hands on or interactive.

In the papers to follow, prescriptive pedagogies will be outlined that seek to take tentative steps to satisfy the industry-identified needs for engineers to more successfully integrate into the workplace, and develop the engineering thinking skills which will facilitate that transition. Specific pedagogies to be discussed will be related to enhancing skills in: critical thinking, problem solving, systems thinking, design thinking, creative/innovative thinking, self-regulated learning, and adaptive expertise.

The educational model builds upon the benefits of service learning in engineering programs by incorporating a number of prerequisites to such engagements. These include: a) philosophy and engineering (epistemology, critical thinking, ethics), b) educational psychology (problem solving, metacognition, self-regulated learning, thinking skills), and c) a cognitive apprenticeship experience to iteratively model expert thinking. The educational model then culminates in d) a community engagement project/internship with a reflection component synthesizing and 
International Journal for Service Learning in Engineering, Humanitarian Engineering and Social Entrepreneurship Vol. 12, No. 1, pp. 74-89, Spring 2017

ISSN 1555-9033

evaluating the cognitive approach taken throughout the experience. This paper's intent is to open the conversation about how to better design holistic engineering learning experiences to enhance workplace performance and associated thinking skills. 
International Journal for Service Learning in Engineering, Humanitarian Engineering and Social Entrepreneurship Vol. 12, No. 1, pp. 74-89, Spring 2017

ISSN 1555-9033

\section{REFERENCES}

${ }^{1}$ National Academy of Engineering, The Engineer of 2020: Visions of Engineering in the New Century, The National Academies Press, Washington, D.C., 2004

${ }^{2}$ National Academy of Engineering, Educating the Engineer of 2020: Adopting Engineering Education to the New Century, The National Academics Press, Washington, D.C., 2005

${ }^{3}$ American Society for Engineering Education Deans Council and Corporate Roundtable, The Green Report: Engineering Education for a Changing World, ASEE, Washington, D.C., 1994

${ }^{4}$ Rugarcia, A., Felder, R. M., Woods, D. R., \& Stice, J. E. (2000). The future of engineering education I. A vision for a new century. Chemical Engineering Education, 34(1), 16-25.

${ }^{5}$ Shute, V. J., \& Becker, B. J. (2010). Innovative assessment for the 21st century. New York, NY: Springer-Verlag.

${ }^{6}$ Redish, E.F., Smith, K.A., (2013). Looking Beyond Conent: Skill Developent for Engineers. Journal of Engineering Education, 97 (3), 295-308.

${ }^{7}$ Hatano, G. and K. Inagaki. 1986. Two Courses of Expertise. Child development and education in Japan. In H. Stevenson, H. Azuma, and K. Hakuta, (Eds.): W. H. Freeman, 262-272.

8 Pellegrino, J. W. 2006. Rethinking and redesigning curriculum, instruction and assessment: What contemporary research and theory suggests.

http://www.skillscommission.org/pdf/commissioned_papers/Rethinking\%20and\%20Redesignin g.pdf (accessed September 15, 2016).

${ }^{9}$ Wesner, J.W., 2006. What We Have Learned in Mudd Design Workshop V: Learning and Engineering Design. International Journal of Engineering Education, Vol. 22, No. 3, pp. 685-688.

${ }^{10}$ Bezdek, M., Helvick D., Mercado R., Rover D., Tyagi A., Zhang Z., 2006. Developing and Teaching an Integrated Series of Courses in Embedded Computer Systems. 36 $6^{\text {th }}$ ASEE/IEEE Frontiers in Education Conference. 1-42440257-3/06/.

${ }^{11}$ The National Academy of Engineering, Educating the Engineer of 2020: Adapting Engineering Education to the Next Century, The National Academies Press, 2005.

${ }^{12}$ Rugarcia, A., Felder R.M., Woods, D.R., Stice, J.E., (2000). The Future of Engineering Education - A Vision for a New Century. Chemical Engineering Education, 34(1), 16-25.

13 "Knowledge Structure." Series of articles in Chem. Engr. Education, 27(2), 78-116 (1993)

${ }^{14}$ Rugarcia, Armando, Felder, R.M., Woods, Donald R., Stice James E. The Future of Engineering Education I. A Vision for a New Century. Chem. Engr. Education, 34(1), 16-25 (2000).

15 J.M. Prausnitz, "Integration of Knowledge is the Key to Versatility." Chemical Engineering Progress, Jan. 1988, p. 7

16 J.M. Prausnitz, "Chemical Engineering and the Other Humanities." Chem. Engr. Education, 32(1), $14-19$ (1998).

${ }^{17}$ N. Longworth and W.K. Davies, Lifelong Learning. Kogan Page, London, 1996.

18 Johnson, S. D. (1992). A framework for technology education curricula which emphasizes intellectual processes. Journal of Technology Education, 3(2), 26-36.

${ }^{19}$ Dhillon, A. S. (1998). Individual differences within problem-solving strategies used in physics. Science Education, 82, 379-405

${ }^{20}$ de Jong, T. (2006). Computer simulations: Technological advances in inquiry learning. Science, 312, $532-533$.

${ }^{21}$ Atman, C. J., Sheppard, S. D., Turns, J., Adams, R. S., Fleming, L. N., Stevens, R., . . Lund, D. (2010). Enabling engineering student success: The final report for the Center for the Advancement of Engineering Education.

22 Hicks, N. M., \& Bumbaco, A. E., \& Douglas, E. P. (2014, June), Critical Thinking, Reflective Practice, and Adaptive Expertise in Engineering Paper presented at 2014 ASEE Annual Conference \& Exposition, Indianapolis, Indiana. https://peer.asee.org/20233

${ }^{23}$ American Society of Engineering Education, 2013. Transforming Undergraduate Education in Engineering, Phase I: Synthesizing and Integrating Industry Perspectives. Workshop Report, Arlington, VA.

${ }^{24}$ Robinson, M.S., Sparrow, P.R., Clegg, C., Birdi, K. 2005. Design Engineering Competencies: Future Requirements and Predicted Changes in the Forthcoming Decade. Design Studies, Vol. 26, Issue 2, March 2005, pp. $123-153$. 
International Journal for Service Learning in Engineering, Humanitarian Engineering and Social Entrepreneurship Vol. 12, No. 1, pp. 74-89, Spring 2017

ISSN 1555-9033

${ }^{25}$ Crawley, E.F., 2001. The CDIO Syllabus: A Statement of Goals for Undergraduate Engineering Education. MIT CDIO Report \#1.

${ }^{26}$ Martin, T., Rivale, S.D., Diller, K.R., 2007. Comparison of Student Learning in Challenge-based and Traditional Insturction in Biomedical Engineering. Annals of Biomedical Engineering, Vol. 35, No. 8, pp. 1312-1323.

${ }^{27}$ BransfordA. L. Brown and R. R. Cocking. (Eds). How People Learn: MindBrain, Experience, and School. Washington, DC: National Academy Press, pp. 319, 2000

${ }^{28}$ Schwartz, D. L., and J. D. Bransford. A time for telling. Cognition and Instruction. 16:475-522, 1998.

${ }^{29}$ Anderson, J. R. Acquisition of a cognitive skill. Psych. Rev. 89:369-406, 1982

${ }^{30}$ BransfordA. L. Brown and R. R. Cocking. (Eds). How People Learn: MindBrain, Experience, and School. Washington, DC: National Academy Press, pp. 319, 2000

${ }^{31}$ Barron, B. J., D. L. Schwartz, N. J. Vye, A. Moore, A. J. Petrosino, and L. Zech, et al. Doing with understanding: lessons from research on problem- and project-based learning. J. Learn. Sci. 7:271-312, 1998.

${ }^{32}$ BransfordA. L. Brown and R. R. Cocking. (Eds). How People Learn: MindBrain, Experience, and School. Washington, DC: National Academy Press, pp. 319, 2000

${ }^{33}$ Albanese, M. A., and S. Mitchell. Problem-based learning: a review of literature on its outcomes and implementation issues. Acad. Med. 68:52-81, 1993.

${ }^{34}$ Dochy, F., M. Segersb, P. Van den Bosscheb, and D. Gijbels. Effects of problem-based learning: a meta-analysis. Learn Instruct. 13:533-568, 2003.

${ }^{35}$ de Jong, T. Computer simulations: technological advances in inquiry learning. Science. 312:532-533, 2006.

${ }^{36}$ Prince, M. J., and R. M. Felder. Inductive teaching and learning methods: definitions, comparisons, and research bases. J. Eng. Educ. 95:123-138, 2006.

${ }^{37}$ Terezini, P. T., A. F. Cabrera, C. L. Colbeck, and S. A. Bjorklund. Collaborative learning vs. lecture/discussion: students' reported learning gains. J. Eng. Educ. 90:123-129, 2001.

${ }^{38}$ Williams, S. M. (1992). Putting case-based instruction into context: Examples from legal and medical education. Journal of the Learning Sciences, 2(4), 367-427

${ }^{39}$ Hmelo-Silver, C. E. (2004). Problem-based learning: What and how do students learn? Educational Psychology Review, 16, 235-266.

${ }^{40}$ Prince, M. J., \& Felder, R. M. (2006). Inductive teaching and learning methods: Definitions, comparisons, and research bases. Journal of Engineering Education, 95(2), 123-138.

${ }^{41}$ Barron, B. J., Schwartz, D. L., Vye, N. J., Moore, A., Petrosino, A., Zech, L., et al. (1998). Doing with understanding: Lessons from research on problem- and project-based learning. Journal of the Learning Sciences, 7, 271-312.

42 Prince, M. J., \& Felder, R. M. (2006). Inductive teaching and learning methods: Definitions, comparisons, and research bases. Journal of Engineering Education, 95(2), 123-138.

${ }^{43}$ de Jong, T. (2006). Computer simulations: Technological advances in inquiry learning. Science, 312, 532-533.

${ }^{44}$ Dochy, F., Segersb, M., Van den Bosscheb, P., \& Gijbels, D. (2003). Effects of problem-based learning: A metaanalysis. Learning and Instruction, 13(5), 533-568.

${ }^{45}$ de Jong, T. (2006). Computer simulations: Technological advances in inquiry learning. Science, 312, 532-533.

${ }^{46}$ Prince, M. J., \& Felder, R. M. (2006). Inductive teaching and learning methods: Definitions, comparisons, and research bases. Journal of Engineering Education, 95(2), 123-138.

${ }^{47}$ Atman, C. J., Sheppard, S. D., Turns, J., Adams, R. S., Fleming, L. N., Stevens, R., . . Lund, D. (2010). Enabling engineering student success: The final report for the Center for the Advancement of Engineering Education.

Retrieved from http://www.engr.washington.edu/ caee/CAEE\%20final\%20report\%2020100909.pdf

${ }^{48}$ Greene, M.T., Papalambros, P.Y. A cognitive framework for engineering systems thinking. 2016 Conference on Systems Engineering Research.

${ }^{49} \mathrm{http}: / /$ plato.stanford.edu/entries/properties-emergent/

${ }^{50}$ Fromm, J. Types and Forms of Emergence. Distributed Systems Group, Universitat Kassel, Germany

${ }^{51}$ McKeachie, Wilbert J. "Cognitive skills and their transfer: Discussion." International Journal of Educational Research11.6 (1987): 707-712. 
International Journal for Service Learning in Engineering, Humanitarian Engineering and Social Entrepreneurship Vol. 12, No. 1, pp. 74-89, Spring 2017

ISSN 1555-9033

52 Dixon, Raymond A., and Ryan A. Brown. "Transfer of learning: Connecting concepts during problem solving." Journal of Technology Education. Vol. 24, No. 1. Fall 2012.

${ }^{53}$ Dweck, C. (1989). Motivation. In L. Lesgold, \& R. Glaser, Foundations for a Psychological Education (pp. 87-136). Hillsdale, $\mathrm{N} \mathrm{J}$ : Erlbaum.

${ }^{54}$ Ericsson, K. A., Krampe, R. T., \& Tesch-Romer, C. (1993). The role of deliberate practice in the acquisition of expert performance. Psychological Review , 100(3), 363-406.

55 Johnson, S. D., Dixon, R., Daugherty, J., \& Lawanto, O. (2011). General versus specific intellectual competencies: The question of learning transfer. In M.Barak \& M. Hacker (Eds.), Fostering Human Development through Engineering and Technology Education (pp. 55-74). Netherlands: Sense Publishers.

${ }^{56}$ Palinscar, A., \& Brown, A. L. (1984). Reciprocal teaching of comprehension monitoring activities. Cognition and Instruction, 1, 117-175.

${ }^{57}$ Singley, A., \& Anderson, J. R. (1989). The transfer of cognitive skill . Cambridge, M A: Harvard University Press.

${ }^{58}$ Salomon, G. 1988, April. Two Roads to Transfer; Two Roads of Transfer. Paper presented at the annual meeting of the American Educational Research Association. New Orleans.

${ }^{59}$ Sutton, M. J. (2003). Problem representation, understanding, and learning transfer: Implications for technology education research. Journal of Industrial Teacher Education, 40 (4), 47-61.

60 Johnson, S. D. (1995). Transfer of learning. The Technology Teacher, 54 (7), 33-35.

${ }^{61}$ National Research Council. (2000). How people learn: Brain, mind, experience and school. Washington, DC: National Academy Press.

${ }^{62}$ Schunn, C.D., \& Silk, E. M. (2011). Learning theories for engineering and technology education. In M. Barak \& M. Hacker (Eds.). Fostering Human Development through Engineering and Technology Education (pp. 55-74).

Netherlands: Sense Publishers.

${ }^{63}$ Spiro, R. J., Feltovitch, P. L., Jackson, M. L., \& Coulton, R. L. (1991). Cognitive flexibility, constructivism, and hypertext: Random access instruction for advanced knowledge acquisition in ill-structured domain. Educational Technology 31 (5), 24-33.

${ }^{64} \mathrm{Hey}$, J., Linsey, J., Agogino, A. M., \& Wood, K. L. (2008). Analogies and metaphors in creative design. International Journal of Engineering Education, 24 (2), 283-294.

${ }^{65}$ Lewis, T. (2008). Creativity in technology education: Providing children with glimpses of their inventive potential. International Journal of Technology and Design Education, 19 (3), 255-258.

${ }^{66}$ Paivio, A. (1990). Mental representations. New York, NY: Oxford University Press.

${ }^{67}$ Gick, M., \& Holyoak, K. J. (1983). Schema induction and analogical transfer.Cognitive Psychology, 15, 1-38.

${ }^{68}$ Perfetto, G. A., Bransford, J. D., \& Franks, J. J. (1983). Contraints on access in a problem solving context. Memory and Cognition, 11, 24-31.

${ }^{69}$ Hmelo-Silver, C. (2004). Problem-based learning: What and how do students learn? Educational Psychology, $16(3), 235-266$.

${ }^{70}$ Branker, K. Pearce, J., McCorbett, J., and J. Webster, "Hybird Virtual-and Field Worked-Based Service Learning with Green Information Technology and Systems Projects." International Journal for Service Learning in Engineering 5(2), pp. 44-59 (2010) http://library.queensu.ca/ojs/index.php/ijsle/article/view/3166

${ }^{71}$ R. G. Bringle \& J. A. Hatcher. Implementing service learning in higher education. Journal of Higher Education, 67, (1996) 221-39.

${ }^{72}$ A.Driscoll, Holland, B., Gelmon, S. \& Kerrigan, S. "An assessment for service learning: Comprehensive case studies of impact on faculty, students, community and institution" Michigan Journal of Community Service Learning, 3, (1996) 66-71.

${ }^{73}$ D. Panini, \& Lasky. K. Service learning's foothold in communication scholarship. Journalism \& Mass Communication Educator, 57(2), (2002), 113-125.

${ }^{74}$ S.M. Gallini \& Moely, B.E. Service-Learning and Engagement, Academic Challenge, and Retention, Michigan Journal of Community Service Learning, 10(1), (2003) 5-14.

75 D. Riley \& Bloomgarden, A. H. Learning and Service in Engineering and Global Development. International Journal for Service Learning in Engineering 2(1), (2006), 48-59. 
International Journal for Service Learning in Engineering, Humanitarian Engineering and Social Entrepreneurship Vol. 12, No. 1, pp. 74-89, Spring 2017

ISSN 1555-9033

${ }^{76}$ C. George, \& Shams, A. Challenge of Including Customer Satisfaction Into the Assessment Criteria of Overseas Service-Learning Projects, International Journal for Service Learning in Engineering, 2(2), (2007), 64-75.

${ }_{77}$ C. Keen \& Hall, K. Post-Graduation Service and Civic Outcomes for High Financial Need Students of a MultiCampus, Co-Curricular Service-Learning College Program. Journal of College and Character, 10(2), Article 2. (2008). DOI: $10.2202 / 1940-1639.1066$

${ }^{78}$ J.M. Pearce \& ter Horst, E. Service Learning for Sustainable Development in Languages, in Filho, W.L. Editor, Sustainability at Universities: Opportunities, Challenges and Trends, (Peter Lang Scientific Publishers: New York, 2009) 73-85.

${ }^{79}$ Bielefeldt, A. R., \& Pearce, J. M. (2012). Service Learning in Engineering. In T. H. Colledge (Ed.), Convergence: Philosophies and Pedagogies for Developing the Next Generation of Humanitarian Engineers and Social Entrepreneurs (pp. 24-52): NCIIA. http://digitalcommons.mtu.edu/materials_fp/54

${ }^{80}$ Kellogg Commission on the Future of State and Land-Grant Universities. (1999). Returning to our roots: The engaged institution. Washington, DC: National Association of State Universities and Land-Grant Colleges.

$81 \mathrm{~J}$. Eyler and D.E. Giles, Where's the Learning in Service Learning? (San Francisco,

CA: Jossey-Bass: 1999).

82 J.A. Boss, "[?] Effects of Community Service Work on the Moral Development of College Ethics Students", Journal of Moral Education 23, (1994), 183-198.

83 J. Eyler, S. Root, and D.E. Giles, "Service Learning and the Development of Expert Citizens: Service Learning and Cognitive Science", In R. Bringle and D. Duffy (eds.) With Service in Mind (Washington, D.C.: American Association of Higher Education, 1998).

${ }^{84}$ J. Cohen and D. Kinsey, "Doing Good and Scholarship: A Service Learning Study," Journalism Educator 4, (1994) 14.

85 J. Miller, "Linking Traditional and Service Learning Courses: Outcome Evaluations Utilizing Two Pedagogically Distinct Models," Michigan Journal of Community Service Learning 1, no. 1 (1994), 29-36.

${ }^{86}$ Bielefeldt, A.R., M.M. Dewoolkar, K.M. Caves, B.W. Berdanier, and K.G. Paterson. 2011. Diverse Models for Incorporating Service Projects into Engineering Capstone Design Courses. International Journal of Engineering Education, 27(6) 1206-1220.

${ }^{87}$ ABET (2010). Criteria for Accrediting Engineering Programs, Effective for Evaluations During the 2011-2012 Accreditation Cycle, 26 pp., ABET Engineering Accreditation Commission. www.abet.org

${ }^{88}$ American Society of Civil Engineers (ASCE). 2008. Civil Engineering Body of Knowledge for the 21st Century: Preparing the Civil Engineer for the Future, $2^{\text {nd }}$ edition, 191 pp., ASCE, 2008. www.asce.org.

89 Jaeger, B. and E. LaRochelle. 2009. EWB^2 - Engineers Without Borders: Educationally, a World of Benefits. American Society for Engineering Education (ASEE) Annual Conference. Paper AC 2009-740.

${ }^{90}$ Duffy, J., E. Tsang, S. Lord. 2000. Service-Learning in Engineering: What, Why, and How? American Society for Engineering Education (ASEE) Annual Conference. Paper AC 2006-3630.

${ }^{91}$ Hobson, R.S. 2000. Service-Learning as an Educational Tool in an Introduction to Engineering Course. American Society for Engineering Education (ASEE) Annual Conference. Paper AC 2000-session 3253. 10 pp.

${ }^{92}$ Zarske, M.S., D.T. Reamon, D. Knight. 2011. Altruistic Engineering Projects: Do project-based service learning designs impact attitudes in first-year engineering students? American Society for Engineering Education (ASEE) Annual Conference. Paper AC 2011-968.

${ }^{93}$ Bielefeldt, A.R., M.M. Dewoolkar, K.M. Caves, B.W. Berdanier, and K.G. Paterson. 2011. Diverse Models for Incorporating Service Projects into Engineering Capstone Design Courses. International Journal of Engineering Education, 27(6) 1206-1220.

${ }^{94}$ Dewoolkar, M. M., George, L. A., Hayden, N. J., and Rizzo, D. M. (2009), "Vertical integration of service-learning into civil and environmental engineering curricula", International Journal of Engineering Education 56(6), 12571269.

${ }^{95}$ Terpenny, J., R. Gao, J. Ritter, D. Fisher, and S. Krishnamurty. 2001. Senior Design Projects to Air the Disabled. American Society for Engineering Education (ASEE) Annual Conference. Paper Session 2325, 11 pp. 
International Journal for Service Learning in Engineering, Humanitarian Engineering and Social Entrepreneurship Vol. 12, No. 1, pp. 74-89, Spring 2017

ISSN 1555-9033

${ }^{96}$ Duffy, J., C. Barry, L. Barrington, D. Kazmer, W. Moeller, C. West. 2008. Service-learning projects in 35 core undergraduate engineering courses. American Society for Engineering Education (ASEE) Annual Conference. Paper AC 2008-1525. 20 pp.

${ }^{97}$ Duffy, J., L. Barrington, M. Heredia. 2009. Recruitment, retention, and service learning in engineering. American Society for Engineering Education (ASEE) Annual Conference. Paper AC 2009-2138. 27 pp.

${ }^{98}$ Romkey, L. The development and assessment of critical thinking for the global engineer. in Proc. 2009 Am. Soc. Eng. Educ. Conf. (2009).

${ }^{99}$ Mina, M., Omidvar, I. \& Knott, K. Learning to think critically to solve engineering problems: revisiting John Dewey's ideas for evaluating the engineering education [CDROM]. Retrieved January 5, 2004 (2003).

100 . Ahern, A., O'Connor, T., McRuairc, G., McNamara, M. \& O'Donnell, D. Critical thinking in the university curriculum - the impact on engineering education. Eur. J. Eng. Educ. 37, 125-132 (2012).

${ }^{101}$ Donawa, A., Martin, C. \& White, C. Re-engineering engineering: Teaching Students How to Think Critically. in Proc. 2007 Am. Soc. Eng. Educ. Conf. (2007).

${ }^{102}$ Andrews, T. \& Patil, R. Information literacy for first-year students: an embedded curriculum approach. Eur. J. Eng. Educ. 32, 253-259 (2007).

${ }^{103}$ Prince, M. J. \& Felder, R. M. Inductive teaching and learning methods: Definitions, comparisons, and research bases. Journal of Engineering Education 95, 123-138 (2006). 